\title{
Kävisikö kauppa peltomaisemista: onko asukkailla kiinnostusta ostaa ja pellonomistajilla halukkuutta myydä maisemapalveluja?
}

Eija Pouta, Maija Salmiovirta, Katriina Soini, Tapani Kivinen, Marja Uusitalo

MTT, Maa- ja elintarviketalouden tutkimuskeskus, Luutnantintie 1300410 Helsinki, etunimi.sukunimi@mtt.fi

Viimeaikoina on etsitty markkinalähtöisiä keinoja tuottaa suojelu-, virkistys- ja maisemapalveluja. Markkinalähtöinen tapa tuottaa maisemapalveluita voisi olla maisema-arvokauppa. Hyödykkeen ostajia olisivat paikalliset asukkaat, jotka ostaisivat maisemapalveluja alueen maanomistajilta ja viljelijöiltä. Maisemapalvelut voisivat olla esimerkiksi maatalouden ympäristötuen ulkopuolelle jääviä maisemanhoitotoimenpiteitä tai maaseutumaisemien ylläpitoa. Maisemaan liittyvät hyödyt muodostuvat maiseman käyttöarvoista maiseman katselun kautta ja ovat hyvin paikallisia. Maisema-arvokaupan toteuttaminen edellyttäisi paikallisesta halukkuutta maksaa maisema-arvoista, tarjota niitä sekä yhteistä sopimusta maisema-arvokaupan ehdoista.

Kansalaisten halukkuutta maksaa maisemansuojelusta maisema-arvokaupan kautta on tutkittu ehdollisella arvottamisella ja valintakokeella vuonna 2008 kerätyn kyselyaineiston pohjalta (N 630). Kyselyssä esitettiin vastaajille erilaisia maisemanhoitotoimenpiteitä, joilla vaikutettaisiin alueen viljelymaisemiin. Toimenpiteet vaikuttaisivat erityisesti viljelemättömän pellon osuuteen, kasvilajien lukumäärään, laiduntaviin eläimiin, suojavyöhykkeisiin ja talousrakennusten kuntoon. Uudenlaisten maisemanhoitokäytäntöjen toteutustavaksi kuvattiin asukkaiden ja maanomistajien välinen maisemaarvokauppa, jossa asukkaat rahoittaisivat yhdessä maanomistajien kanssa kymmenen vuoden aikana toteuttaman maisemanhoito-ohjelman.

Ehdollisen arvottamisen menetelmä paljasti maisemanhoito-ohjelman kannatuksen eri kustannustasoilla. Ohjelman kannatus aleni maisema-arvokaupan aiheuttamien kustannusten kasvaessa. Jos ohjelman ei oletettu aiheuttavan kustannuksia, 81 \% vastaajista kannatti sitä. Kotitaloudelle aiheutuvien kustannusten noustessa ohjelman kannatus laski. Puolet vastaajista kannatti ohjelmaa noin 86 euron vuotuisella kustannustasolla, mitä voidaan pitää yhtenä esitetyn maisemanhoito-ohjelman maksuhalukkuuden keskilukuna (ei-parametrinen mediaani). Toteutettu valintakoe paljasti, että esitetyistä maisemanhoitotoimista erityisesti laiduntavat eläimet sekä kunnostetut talousrakennukset sekä myös luonnontilaiset suojavyöhykkeet vaikuttivat vastaajien halukkuuteen osallistua ohjelmaan.

Maanomistajien halukkuus osallistua maisema-arvokauppaan oli heikko, sillä $48 \%$ vastaajista oli haluttomia osallistumaan, tai he olivat asiasta epävarmoja (41\%). Vastanneista maanomistajista 11 prosenttia oli halukaita osallistumaan esitetynlaiseen maisema-arvokauppaan. Toimenpiteet, jotka kiinnostivat maanomistajia, liittyivät peltoalan säilyttämiseen viljelyssä ja talousrakennusten kunnostamiseen. Omistajat toivoivat useimmiten saavansa maisema-arvokauppaan liittyvistä toimenpiteistä korvausta joko kustannusten verran tai enemmän kuin kustannukset. Reilu 10-20 \% omistajista olisi valmis tyytymään kustannuksia vähäisempään maisema-arvojen korvaustasoon toimenpiteestä riippuen.

Lähes puolet vastaajista piti maisema-arvokauppaa hyvänä keinona suojella alueen maisemia, mutta hieman alle $40 \%$ oli epävarma maisema-arvokaupasta. Erityisesti maisema-arvokaupan toteutumista pidettiin epävarmana ja epäiltiin käytännön järjestelyjen hankaluutta.

Asiasanat: Maksuhalukkuus, maisema-arvokauppa, maisema-arvot, maaseutumaisema 


\section{Johdanto}

Vuonna 2000 laadittu Eurooppalainen maisemayleissopimus hyväksyttiin Suomessa vuoden 2005 lopussa ja se astui voimaan huhtikuussa 2006 (Ympäristöhallinto 2007). Sopimus edellyttää muun muassa maisemanäkökohtien huomioon ottamista eri alojen politiikan laatimisessa sekä toimintaohjelmissa. Sopimuksen pohjalta myös kansalaisten ja viranomaisten tietoisuutta maisemakysymyksistä tulisi lisätä. Lisäksi sopimus edellyttää maisemien analysointia, arvottamista ja muutosten seuraamista sekä maiseman laadullisten tavoitteiden asettamista (Eurooppalainen maisemayleissopimus 2005). Näin ollen Suomi on sitoutunut huolehtimaan maatalousmaiseman säilymisestä ja arvottamisesta. Sopimus tuo esille lisäksi sen, että eri kansalaisryhmät voivat arvottaa maisemaa eri tavoin. Eurooppalainen maisemayleissopimus luo näin myös tilauksen taloustieteelliselle maisemahyötyjen ja -haittojen arvottamiselle.

Se, että maiseman arvoa ei voida suoraan päätellä markkinahinnoista, kuten markkinoilla vaihdettavien tuotteiden arvo voidaan, johtuu maiseman julkishyödykeluonteesta. Julkishyödykkeelle tyypillisiä piirteitä ovat ei-kilpailevuus (nonrivalry) ja ei-poissuljettavuus (nonexludability). Toisin sanoen yhden henkilön julkishyödykkeen käyttö ei vähennä hyödykkeen saatavuutta muille ja hyödykkeen käyttöoikeutta ei voida rajata ainoastaan siitä maksaville (Bateman ym. 2002). Julkishyödykeluonteen vuoksi maiseman hoidon tai suojelun arvoa ei voida päätellä markkinahinnoista.

Suomalainen viljelymaisema on muutoksessa (Heikkilä 2008), muutoksen suunta ja luonne vaihtelee maan eri osissa. Viljelymaiseman muutosten kansalaisille tuottamia hyötyjä tai haittoja ei ole juurikaan arvioitu taloustieteen arvottamismenetelmin. Euroopassa ja USA:ssa tehtyjen maisemahyötyjä arvottavien tutkimusten tuloksista voidaan todeta maaseutumaiseman hoitamisen arvo positiiviseksi ja jopa huomattavaksi (Dillman \& Bergstrom 1991, Ready ym. 1997, Hackl \& Pruckner 1997, Rosenberger \& Walsh 1997). Maatalousmaiseman markkinattomien hyötyjen on todettu olevan suurempia kuin maatalouden tuoton viljelyssä (Fleischer \& Tsur 2000). Viljelymaiseman ominaisuuksista koettuihin hyötyihin ja siten maksuhalukkuuteen vaikuttavat maanpinnan muodot, kasvillisuus ja rakentaminen (Sayadi ym. 2005, Rambonilaza \& Dachary-Bernard 2007). Myös kunkin alueen maaseutukulttuuria kuvastavien maisemapiirteiden ja perinteisten käytäntöjen suojelusta ollaan valmiita maksamaan (Hanley ym. 2007, Scarpa ym. 2007). Viljapeltojen ja hoidettujen laitumien on todettu lisänneen maiseman arvostusta (Schläpfer ym. 2008). Erityisesti peltojen jättäminen viljelyn ulkopuolelle ja metsittäminen on vähentänyt arvostusta (Raffaelli ym. 2004). Vastaajakohtaisen maatalousmaiseman arvostuksen on todettu olevan sidoksissa yleisempiin ympäristöasenteisiin (Kline \& Wechelns 1998). Maatalousmyönteisyyden on todettu liittyvän myös peltojen ja laidunten korkeampiin maisema-arvoihin. Maisemaan liittyvät aktiviteetit nostavat maksuhalukkuutta maiseman suojelusta (Bonnieux \& LeGoffe 1997). Korkean koulutuksen ja tulojen (Bonnieux \& LeGoffe 1997) sekä kaupungissa asumisen (Schläpfer ym. 2004) on todettu liittyvän korkeampaan maksuhalukkuuteen.

Julkishyödykkeen tarjoajalla, joka ei saa tuottamastaan hyödystä korvausta, ei ole kannustinta tuottaa hyödykettä riittävästi kysyntään nähden. Suorien kannustimien ohella on ehdotettu myös markkinalähtöisiä keinoja rahoittaa suojelu-, virkistys- ja maisema-arvojen tarjontaa (esim. Temisevä 2008). Näin on toimittu $\mathrm{mm}$. metsiensuojelun tarjouskilpailuissa (Juutinen 2005). Maisemahyödykkeen ostajia voisivat olla paikalliset asukkaat, jotka ostaisivat maisemapalveluja alueen maanomistajilta ja viljelijöiltä. Tällaisia maisemapalveluita voisivat olla esimerkiksi maatalouden ympäristötuen ulkopuolelle jäävä maisemanhoito tai viljelymaisemien ylläpito, mikäli omistaja ei ole ympäristötuen piirissä. Markkinalähtöinen tapa tuottaa maisemapalveluita voisi olla maisema-arvokauppa.

Tässä tutkimuksessa arvotetaan maaseutumaiseman hoidon tuottamia kansalaisten kokemia hyötyjä. Lisäksi tutkimuksessa tarkastellaan maanomistajien halukkuutta osallistua maisema-arvokauppaan. Tutkimuksessa esitetään empiiriseen kyselyaineistoon pohjaavia tuloksia maisema-arvokaupan toteutettavuudesta.

\section{Aineisto ja menetelmät}

Tutkimuksen kohdealueeksi valittiin läntisellä Nurmijärvellä sijaitsevan Lepsämänjoen ympäristön peltoaukeat. Alue edustaa hyvin perinteistä uusimaalaista maaseutumaisemaa. Alueelle ominaista on myös 
uuden haja-asutuksen synty. Tutkimusaineisto hankittiin postikyselyllä, joka lähetettiin alueen kotitalouksiin joukkokirjeenä. Muistutuskortin ja uusintapostituksen jälkeen saatiin noin $29 \%$ vastausosuus, mikä tarkoitti 630 vastaajaa.

Tutkimuksessa sovellettiin sekä ehdollisen arvottamisen menetelmää että valintakoemenetelmää.

Suomessa näitä arvottamismenetelmiä on sovellettu erityisesti metsien- ja vesiensuojelun arvottamiseen, mutta menetelmät ovat käyttökelpoisia myös maisema-arvojen määrittämisessä. Menetelmillä selvitetään joko sitä, kuinka paljon kansalaiset olisivat valmiita hyväksymään maiseman hoidon aiheuttamia henkilökohtaisia kustannuksia tai sitä, kuinka paljon kansalaisten tulisi saada kompensaatiota, jotta he hyväksyisivät maiseman laadun heikkenemisen. Kyselyssä on tärkeä määrittää mm. 1) keihin hanke vaikuttaa 2) kuinka hanke vaikuttaa ja 3) miten hankkeesta maksetaan. Kysely- tai haastattelulomakkeella annetaan arvioitavasta kohteesta ja siihen vaikuttavasta hankkeesta tietoa vastaajille, jotta pystytään luomaan heille mielekäs valintatilanne. Tutkimuskohteen ja sen ominaisuuksien muutosta verrataan nykytilaan ja tämä ero esitetään selkeästi. Kyselyssä kuvataan myös hankkeeseen liittyvä toteuttamistapa, vastaajalle aiheutuvan hypoteettisen maksun ajankohta ja maksutapa esimerkiksi maisema-arvokauppa.

Käytettäessä ehdollisen arvottamisen menetelmää kyselyssä vastaajille esitettiin maisemanhoitokäytäntöjä, jolla vaikutettaisiin alueen viljelymaisemiin. Käytäntö vaikuttaisi erityisesti viljelemättömän pellon osuuteen, kasvilajien lukumäärään, laiduntaviin eläimiin, suojavyöhykkeisiin ja talousrakennusten kuntoon (taulukko 1). Uuden maisemanhoitokäytännön toteutustavaksi kuvattiin asukkaiden ja maanomistajien välinen maisema-arvokauppa, jossa asukkaat rahoittaisivat yhdessä maanomistajien kymmenen vuoden aikana toteuttaman maisemanhoito-ohjelman. Tämän jälkeen vastaajalle esitettiin ota tai jätä -tyyppinen kysymys. Siihen vastatessaan vastaaja punnitsee, voisiko hän luopua osasta käytettävissä olevia tulojaan maisemanhoito-ohjelman toteuttamiseksi. Maksuhalukkuuskysymykseen liittyvää hankkeen toteuttamisen kustannusta vaihdeltiin vastaajalta toiselle, jolloin saatiin tietoa hankkeen kannatettavuudesta eri kustannustasoilla ja voitiin laskea keskimääräinen maksuhalukkuus.

Taulukko 1. Vastaajalle esitetty valinta-asetelma ehdollisen arvottamisen kysymyksessä. Kullekin vastaajalle esitettiin sama maisemanhoito-ohjelma, mutta kustannus kotitaloudelle vaihteli 0 eurosta 200 euroon.

\begin{tabular}{lcc}
\hline & Nykytila & Vaihtoehto \\
\cline { 2 - 3 } Viljelemätön pelto & $10 \%$ & $0 \%$ \\
Viljelykasvilajit & 3 & 10 \\
Laiduntavat eläimet & ei eläimiä & hevosia, nautakarjaa \\
Suojavyöhykkeet & $7 \mathrm{~m}$, niitetty & $15 \mathrm{~m}$, luonnontilainen \\
Talousrakennukset & puolet ränsistyneitä & kaikki kunnostettu \\
\hline Kustannus kotitaloudellenne & $\mathbf{0 €} /$ vuosi & $\mathbf{3 0}$ / vuosi \\
\hline Ka09-2018 & $\square$ & $\square$ \\
\hline
\end{tabular}

Valintakoemenetelmän idea on, että hyödykkeiden arvo määräytyy niiden ominaisuuksien perusteella (Bateman ym. 2002, 249). Näin valintakoemenetelmän avulla saadaan tietoa hankkeen ominaisuuksien vaikutuksista sen arvostukseen ja kannatettavuuteen. Tämä on tarpeen kun hankkeen vaikutukset ovat epävarmat. Menetelmän avulla voidaan tuottaa tietoa myös hankkeen yksittäisen ominaisuuden vaikutuksesta arvoon ja eri ominaisuuksien vaihtosuhteista. Valintakoemenetelmässä keskeistä on määrittää julkishyödykkeeseen, esim. maisemaan liittyvät ominaisuudet ja ominaisuuksien mahdolliset muutokset. Valintakokeessa vastaajalle esitettiin kuusi valinta-asetelmaa (esim. taulukko 2), joissa esim. viljelymaiseman eri ominaisuuksien tasot vaihtelivat. Vastaaja vertasi kerrallaan kahta maisemanhoitovaihtoehtoa nykytilaan. Jokaiseen vaihtoehtoon liittyy myös kotitaloudelle kohdistuva maisemanhoitomaksu. 
Taulukko 2. Valintakoemenetelmässä maisema-arvoja tutkitaan asettamalla kyselytutkimuksessa vastaajalle useita valintatilanteita. Näin saadaan tietoa maiseman ominaisuuksien vaikutuksesta maiseman arvoon.

\begin{tabular}{|c|c|c|c|}
\hline Valintatilanne 1 & Nykytila & Vaihtoehto 1 & Vaihtoehto 2 \\
\hline $\begin{array}{l}\text { Viljelemätön pelto } \\
\text { Viljelykasvilajit } \\
\text { Laiduntavat eläimet } \\
\text { Suojavyöhykkeet } \\
\text { Talousrakennukset }\end{array}$ & $\begin{array}{l}10 \% \\
3 \\
\text { ei eläimiä } \\
7 \mathrm{~m}, \text { niitetty } \\
\text { puolet } \\
\text { ränsistyneitä }\end{array}$ & $\begin{array}{c}10 \% \\
10 \\
\text { hevosia, } \\
\text { nautakarjaa } \\
7 \mathrm{~m}, \text { niitetty } \\
\text { kaikki purettu }\end{array}$ & $\begin{array}{c}0 \% \\
5 \\
\text { hevosia } \\
15 \mathrm{~m}, \text { niitetty } \\
\text { puolet } \\
\text { ränsistyneitä }\end{array}$ \\
\hline $\begin{array}{l}\text { Kustannus } \\
\text { kotitaloudellenne } 2009-2018\end{array}$ & $0 € /$ vuosi & $70 € /$ vuosi & $50 € /$ vuosi \\
\hline Kannatan vaihtoehtoa & $\square$ & $\square$ & $\square$ \\
\hline
\end{tabular}

Kummallakin menetelmällä saatuja valintoja selitettiin tilastollisin mallein (logistinen regressio, ehdollinen logit malli). Laadittujen tilastollisten mallien avulla voidaan laskea kohderyhmän keskimääräinen maksuhalukkuus halutuille vaihtoehtoisille hankkeille.

Asukkaiden valintojen lisäksi oltiin kiinnostuneita maanomistajien halukkuudesta tarjota maisemapalveluja. Heille esitettiin kysymys siitä, mitä maisematoimenpiteitä he olisivat halukkaita toteuttamaan maisema-arvokaupan osana ja lisäksi tiedusteltiin korvaustasoa, jolla he olisivat valmiit osallistumaan kauppaan. Maisema-arvokaupan toteuttamiseen liittyviä uskomuksia kartoitettiin väittämin.

\section{Tulokset}

Tutkimuksen alustavien tulosten mukaan vastaajat kokivat maatalouden maisemakysymykset kolmanneksi tärkeimmäksi maatalouden ympäristökysymykseksi vesiensuojelun ja biodiversiteetin suojelun jälkeen. Melko moni vastaajista (44 \%) katsoi maanomistajat motivoituneiksi maatalouden ympäristönsuojeluun. Maisemista huolehtiminen katsottiin (78\% vastaajista) maanomistajien velvollisuudeksi, vaikka sitä ei korvattaisi heille ympäristötuella. Maanomistajien lisäksi maisemanhoitovastuun katsottiin jakautuvan myös maa- ja metsätaloustuotteiden käyttäjille, veronmaksajille sekä alueen asukkaille. Toimiva maatalous katsottiin hyväksi tavaksi huolehtia maisemista (70 \% vastaajista), mutta toivottiin myös sitä, että maatalouden maisemavaikutuksiin kiinnitettäisiin nykyistä enemmän huomiota (74 \%).

Lähes puolet vastaajista piti maisema-arvokauppaa hyvänä keinona suojella alueen maisemia, mutta hieman alle $40 \%$ oli epävarma maisema-arvokaupasta. Erityisesti maisema-arvokaupan toteutumista pidettiin epävarmana ja epäiltiin käytännön järjestelyjen hankaluutta. Lähes 70 \% vastaajista oli sitä mieltä, että kaikkia alueen maanomistajia ei saataisi mukaan maisema-arvokauppaan.

Ehdollisen arvottamisen menetelmä paljasti maisemanhoito-ohjelman kannatuksen eri kustannustasoilla. Ohjelman kannatus aleni maisema-arvokaupan aiheuttamien kustannusten kasvaessa (kuva 1). Jos ohjelman ei oletettu aiheuttavan kustannuksia, $81 \%$ vastaajista kannatti sitä. Kotitaloudelle aiheutuvien kustannusten noustessa ohjelman kannatus laski. Puolet vastaajista kannatti ohjelmaa noin 86 euron vuotuisella kustannustasolla, mitä voidaan pitää yhtenä esitetyn maisemanhoito-ohjelman maksuhalukkuuden keskilukuna (ei-parametrinen mediaani). 


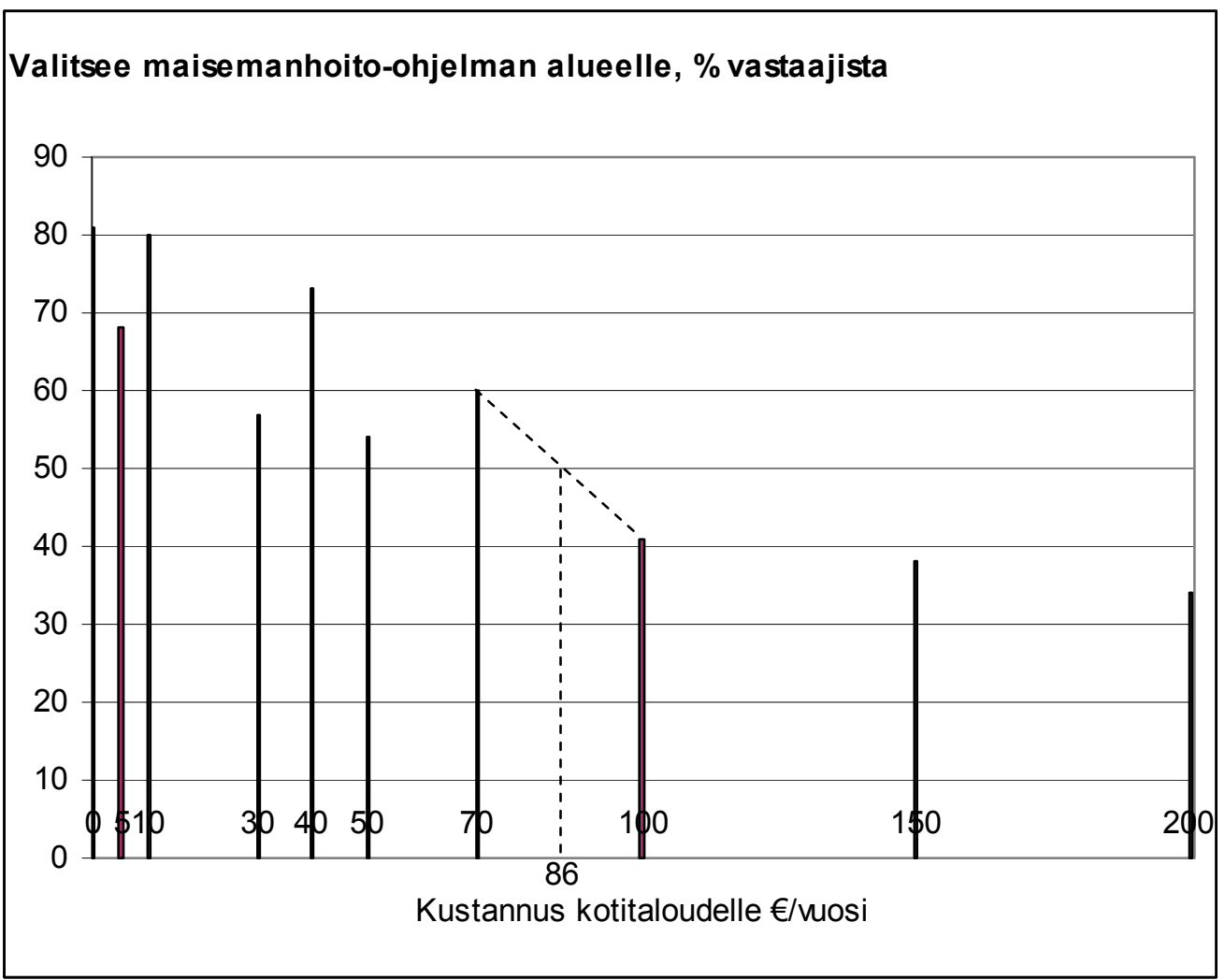

Kuva 1. Kotitalouksien halukkuus hyväksyä maisemanhoito-ohjelma eri kustannustasoilla.

Kyselyssä toteutettu valintakoe paljasti, että esitetyistä maisemanhoitotoimista erityisesti laiduntavat eläimet sekä kunnostetut talousrakennukset sekä myös luonnontilaiset suojavyöhykkeet vaikuttivat vastaajien halukkuuteen osallistua ohjelmaan tai kiinnostivat vastaajia. Valintakokeen ja ehdollisen arvottamisen tulosten perusteella vastaajat olivat valmiita maksamaan maisemanhoitovaihtoehdosta keskimäärin n. 41-102 $€ /$ kotitalous/vuosi menetelmästä riippuen. Kyselyyn vastanneista $12 \%$ ei vastannut yhteenkään valintatilanteista eikä heidän maatalousmaisemaan liittyvistä mieltymyksistään näin ollen ole tietoa. Voidaan kuitenkin olettaa, että heidän maksuhalukkuutensa on keskimääräistä vastaajaa alhaisempi, jolloin myös todellinen keskimääräinen WTP laskee.

Maanomistajien halukkuus osallistua maisema-arvokauppaan oli heikko, sillä $48 \%$ vastaajista oli haluttomia osallistumaan, tai he olivat asiasta epävarmoja (41\%). Vastanneista maanomistajista 11 prosenttia oli halukkaita osallistumaan esitetynlaiseen maisema-arvokauppaan. Toimenpiteet, jotka kiinnostivat maanomistajia, liittyivät peltoalan säilyttämiseen viljelyssä ja talousrakennusten kunnostamiseen. Omistajat toivoivat useimmiten saavansa maisema-arvokauppaan liittyvistä toimenpiteistä korvausta joko kustannusten verran tai enemmän kuin kustannukset. Reilu 10-20 \% omistajista olisi valmis tyytymään kustannuksia vähäisempään maisema-arvojen korvaustasoon toimenpiteestä riippuen.

\section{Lopuksi}

Tulosten perusteella voidaan todeta että taloustieteen arvottamismenetelmät tarjoavat käyttökelpoisen maisema-arvojen mittaamistavan. Tapaustutkimus maatalousmaiseman arvosta Nurmijärvellä paljasti, että maatalousmaiseman hoito on alueella asuville tärkeä asia ja että he olisivat valmiita panostamaan huomattavasti lähiympäristönsä maiseman hoitoon. Viljelymaisemassa arvostetaan erityisesti kunnostettuja latoja ja muita talousrakennuksia sekä laiduntavia eläimiä. Maiseman hoito koetaan yhteiseksi asiaksi, jonka eteen tulisi sekä maanomistajien, asukkaiden kuin viranomaisten tehdä oma osuutensa.

Arvottamismenetelmin voidaan myös tuoda esiin se, kuinka maisema-arvostukset eroavat väestöryhmittäin. Näin päätöksenteossa on mahdollista arvioida vaihtoehtoisten hankkeiden, politiikkojen tai käytäntöjen vaikutusta eri väestöryhmien kokemissa hyödyissä. 
Nykyisin maisemahyötyjen tarjonta pohjautuu pitkälti maanomistajien vapaaehtoiseen maisemanhoitoon, maatalouden ympäristötukeen ja julkisen vallan normiohjaukseen. Tässä artikkelissa tarkasteltiin sitä, voisiko vapaaehtoinen maisema-arvokauppa tarjota vaihtoehtoisia keinoja maisemanhoidon toteuttamiseen. Alustavien tulosten perustella näyttää siltä, että uuden keinon vieminen käytäntöön vaatisi paljon tiedottamista, opastusta ja aktivointia sekä paikallisten asukasyhdistysten että maanomistajien parissa. Nykyisellään maanomistajista vain pieni osa olisi ennakkoluulottomasti halukas maisema-arvokaupan tapaiseen kokeiluun.

\section{Viitteet}

Bateman, I. J., Carson, R. T., Day, B., Hanemann, M., Hanley, N., Hett, T., Jones-Lee, M., Loomes, G., Mourato, S., Özdemiroglu, E., Pearce, D. W., Sudgen, R. \& Swanson, J. 2002. Economic Valuation with Stated Preference Techniques: A Manual. Cheltenham, UK: Edward Elgar.

Bonnieux, F. \& Le Goffe, P. 1997. Valuing the Benefits of Landscape Restoration: a Case Study of the Cotentin in Lower-Normandy, France. Journal of Environmental Management 50, 321-333.

Dillman, B. \& Bergstrom, J. 1991. Measuring environmental amenity benefits of agricultural land. In N. Hanley (ed.), Farming and the Countryside: An Economic Analysis of External Costs and Benefits. London: C.A.B. International, 250-271.

Fleischer, A. Tsur, Y. 2000. Measuring the Recreational Value of Agricultural Landscape. European Review of Agricultural Economics, 27, 3, 385-398.

Hackl, F. \& Pruckner, G. 1997. Towards More Efficient Compensation Programmes for Tourists' Benefits From Agriculture in Europe. Environmental and Resource Economics 10, 2, 189-205.

Hanley, N., Colombo, S., Mason, P. \& Johns, H. 2007. The Reform of Support Mechanisms for Upland Farming: Paying for Public Goods in the Severely Disadvantaged Areas of England. Journal of Agricultural Economics 58, 3, 433-453.

Juutinen A. 2005. Luonnonarvokaupan kustannustehokkuus: kokeiluhanke Lounais-Suomen metsäkeskuksen alueella. Metsätieteen aikakauskirja 2/2005.

Kline, J. \& Wechelns, D. 1998 Measuring heterogeneous preferences for preserving farmland and open spaces, Ecological Economics. 26, 211-224.

Raffaelli, R., Notaro, S., Goio, I. \& Gios, G. 2004. Multifunctional agriculture, policies and markets: understanding the critical linkage. In: 90th EAAE Seminar, Multifunctional agriculture, policies and markets: understanding the critical linkage, Proceedings of 90th EAAE Seminar, Rennes, October 28-29, 2004.

Rambonilaza, M. \& Dachary-Bernard, J. 2007. Land-use planning and public preferences: What can we learn from choice experiment method? Landscape and Urban Planning 83, 318-326.

Ready, R.C., M.C. Berger, and G.C. Blomquist. 1997. Measuring amenity benefits from farmland: Hedonic pricing vs. contingent valuation. Growth and Change 28 (Fall) 438-458.

Rosenberger,R. \& Walsh, R. 1997. Nonmarket value of western valley ranchland using contingent valuation. Journal of Agricultural and Resource Economics 222 296-309. 
Sayadi, S., Gonzalez Roa, M. C. \& Calatrava Requena, J. 2005. Ranking versus scale rating in conjoint analysis: Evaluating landscapes in mountainous regions in southeastern Spain. Ecological Economics 55, 4, $539-550$

Scarpa, R., Campbell, D. \& Hutchinson, W. G. 2007. Benefit Estimates for Landscape Improvements: Sequential Bayesian Design and Respondents' Rationality in a Choice Experiment. Land Economics 83, 4, 617-634.

Schläpfer, F., Roschewitz, A., Hanley, N. 2004. Validation of stated preferences for public goods: a comparison of contingent valuation survey response and voting behaviour. Ecological Economics 51, 1- 16.

Schläpfer, F., Schmitt, M. \& Roschewitz, A. 2008. Competitive politics, simplified heuristics, and preferences for public goods. Ecological Economics 65, 574-589.

Temisevä, M. 2008. Maisema- ja virkistysarvokauppa: Kansainväliset käytännöt ja niiden soveltaminen Suomessa. Helsingin yliopisto. Metsäekonomian laitos. Pro gradu -tutkielma.

Ympäristöhallinto 2007. Eurooppalainen maisemayleissopimus. Päivitetty 30.8.2007. Viitattu 20.3.2008 $<$ http://www.ymparisto.fi/default.asp?contentid=81418\&lan=fi $>$ 